\title{
GENOTYPE-ENVIRONMENT INTERACTION AND STRESS SUSCEPTIBILITY INDEX IN EGYPTIAN COTTON (Gossypium barbadense L.) \\ Mohamed, A. A. ${ }^{1}$; M. A. Ali ${ }^{2}$ and A. M. Mahmoud ${ }^{3}$ \\ 1- Shandaweel Research Station, A. R. C., Egypt. \\ 2- Agronomy Department, Fac. of Agric., South Valley Univ., Qena, Egypt. \\ 3- Agronomy Department, Fac. of Agric., Assiut Univ., Assiut, Egypt.
}

\begin{abstract}
Nine Egyptian cotton genotypes ( 8 varieties and one hybrid) were evaluated under eight different environments i.e., two years (2004 and 2005), two locations represent two major soil types (clay and sandy loam) and two sowing dates. Genotype $x$ year and genotype $x$ sowing dates interaction were highly significant for all studied traits. Also, genotype $\mathrm{x}$ year $\mathrm{x}$ location $\mathrm{x}$ sowing dates interaction was highly significant for seed cotton yield/plant, lint yield, seed index and lint index. Mean seed cotton yield/plant ranged from 21.32 to $29.25 \mathrm{~g}$, from 19.25 to $31.32 \mathrm{~g}$ and from 22.48 to $28.09 \mathrm{~g}$ for locations, sowing dates and years, respectively. Delaying sowing date reduced seed cotton yield/plant, lint yield, boll weight, seed index and lint index.

Stress susceptibility index (S ) was estimated for seed cotton and lint yields/plant. The genotypes Dendara and Giza 45 were relatively stress tolerant in Assiut and Qena for both traits. The highest yielding cultivars in late planting at both locations was Giza 83 (susceptible) followed by Giza 80 and Giza 85 which were tolerant to sowing dates at Qena only. It could be concluded that the policy of planting each cultivar for a particular zone is correct irrespective of their susceptibility to sowing dates, because Giza 83, Giza 80 and Giza 85 are still the best high yielding cultivars at late planting at both of Assiut and Qena governorates.

The stability analysis for seed cotton yield detected that the intermediate yielding genotypes (Dendara, Giza 90, Giza 85 and Giza 89) were stable and ranged in yield from 22.95 to $26.69 \mathrm{~g}$. While the highest yielding genotypes [Giza 80, Giza 83 and (Giza 81x Giza 83)] were unstable.
\end{abstract}

\section{INTRODUCTION}

Cotton is greatly influenced by seasonal and other environmental fluctuations and shows high magnitude of genotype-environment interaction (GE) which provide a major challenge in obtaining a full understanding of genetic control of varieties when compared over series of environments. Also, (GE) interaction exists when the ranks of genotypes show an obvious shift from one environment to another. Such inconsistency is due to two reasons, one being the difference in response of the same set of genes to different environments and the other being the expression of different set of genes in different environments (Falconer, 1952, Robertson, 1959 and Cockerham, 1963). Differences between cotton genotypes in their response to environmental changes have been reported by Miller et al. (1959), Thomson and Cunningham (1979) and Tomar and Singh (1992). El-Feki et al. (1994) indicated that the highest lint yield families i.e., $F_{6} 1108 / 91, F_{6} 1073 / 91$ and $F_{14} 1227 / 91$ finer strains and extra-long varieties exhibited average degree of 
stability. El-Ameen (1994) stated that delaying the sowing date resulted in a substantial reduction in seed cotton yield/plant and lint yield/plant. ElShaarawy et al. (1994), El-Ameen (1994 \& 1999), Hassan (1996) and Sayieda (2001) reported that the $G \times E$ mean squares were highly significant for seed cotton yield and lint yield over a range of environments. Mohamed et al. (2005) found that mean squares due to genotype-environment interaction were highly significant for seed cotton yield, lint yield and boll weight. Moreover, the mean performance of $\mathrm{H}_{8}$ 244/2001 genotype was greatest under favourable environment for these traits, while the genotype $\mathrm{H}_{7}$ 226/2001 was the highest mean under bad environment conditions for seedcotton and lint yields.

Genotype-environmental (GE) interaction reduce association between phenotypic and genotypic expression, and may cause selections in one environment to perform poorly in another. Measuring (GE) interactions is also important to determine the optimum breeding strategy for releasing genotypes with adequate adaptation to target environments (Romagosa and Fox, 1993). Therefore, the aim of this study was to investigate, the magnitude of the genotype-environment interaction for some economic traits of nine Egyptian-cotton genotypes, with the view of characterizing each genotype according to stability over a wide agro-climatic range of conditions.

\section{MATERIALS AND METHODS}

This study included nine genotypes of Egyptian-cotton (Gossypium barbadense L.). Eight of them are cultivars, viz., Dendara(Giza 31), Giza-90, Giza-45, Giza-85, Giza-80, Giza-83, Giza-70 and Giza-89 and one hybrid (Giza-81 x Giza-83). These genotypes were evaluated in eight environments i.e.; two seasons (2004 and 2005), two locations differed in their climatic factors and representing two major soil types of Egypt; Assiut Univ. Exper. Farm (optimal environment) and Qena Exp. Farm, Faculty of Agric., South Valley University (sub-optimal environment) and two planting dates; $15^{\text {th }}$ March (early date) and $25^{\text {th }}$ April (late date). The soil type at Assiut is clay soil $(\mathrm{PH}=7.8$, organic matter $=1.15$, total $\mathrm{N}(\mathrm{ppm})=15.0, \mathrm{P}(\mathrm{ppm})=11.0$ and $\mathrm{K}(\mathrm{ppm})=315.0)$ and much more fertile than at Qena sandy loam soil $(\mathrm{PH}=$ 8.12, organic matter\% $=0.35$, total $\mathrm{N} \%=0.04, \mathrm{P}(\mathrm{ppm})=9.4$ and $\mathrm{K}(\mathrm{meq} / 100 \mathrm{~g}$ soil) was 0.19 and calcium carbonate (\%) was 13.6). The experimental design was a split-plot in RCBD of three replications. The dates were located in the main plots, while the genotypes were assigned randomly at the subplots. Each sub-plot consisted of two rows $4 \mathrm{~m}$ long, $60 \mathrm{~cm}$ between rows and $25 \mathrm{~cm}$ between hills within a row. Seedling were thinned to two plants/hill. All cultural practices were applied as recommended for cotton production. The following traits were recorded for each plant:

1 - Seed cotton yield/plant (g). $\quad 2$ - Lint yield/plant (g).

3- The boll weight $(\mathrm{g})$. $\quad 4$ - Seed index (weight of 100 seeds $\mathrm{g}$ ).

5- Lint index (g) (weight of lint from 100 seeds). 


\section{Statistical analysis}

The combined analysis of variance was performed according to Gomez and Gomez (1984) after carrying out the homogeneity test. Stress susceptibility index was calculated according to Fischer and Maurer (1978) equation:

$S=(1-Y d / Y p) / D$

Where:

$Y d=$ mean yield in stress environment

$Y p=$ mean yield in non-stress environment

$\mathrm{D}=$ environmental stress intensity;

= 1- ( mean Yd of all genotypes / mean Yp of all genotypes $)$.

The stability parameters suggested by Eberhart and Russell (1966) were also computed.

\section{RESULTS AND DISCUSSIONS}

The differences between years and locations were highly significant for all studied traits (Table 1), indicating wide range in climatic and edaphic factors prevailing at the two locations. Highly significant differences was detected between sowing dates for all traits as it would be expected for early and late sowing dates. Highly significant differences due to genotypes were observed for all traits, showing wide genetic diversity among the genotypes for these traits. Moreover, The interactions of year $x$ location and year $x$ sowing date were highly significant for all traits. Also, The interaction of location $\mathrm{x}$ sowing date was highly significant for seed cotton yield/plant and lint yield/plant. The second order interaction year $\mathrm{x}$ location $\mathrm{x}$ sowing date was highly significant for all studied traits, except boll weight. However, The first, second as well as third order interactions which included the genotypes were highly significant for all traits, except year $\mathrm{x}$ location $\mathrm{x}$ sowing date $\mathrm{x}$ genotypes interaction for boll weight (Table 1 ). These results reflect the sensitivity of these genotypes to environmental changes suggesting the assessment of best high yielding genotypes for a particular environment as well as finding the stable ones over such array of conditions.

\section{a- Mean performance of cotton genotypes: \\ 1- Seed cotton yield/plant $(\mathrm{g})$ :}

Mean seed cotton yield/plant ranged from 21.32 to $29.25 \mathrm{~g}$, from 19.25 to $31.32 \mathrm{~g}$ and from 22.48 to $28.09 \mathrm{~g}$ for locations, sowing dates and years, respectively (Table 2). The early sowing date gave 37.80 and 25.00 compared with 20.69 and $17.64 \mathrm{~g}$ produced from late sowing date at the $\mathrm{L}_{1}$ and $L_{2}$, respectively (Table 3 ). Genotypes observed differential responses for either dates or locations for seed cotton yield (Table 3 ). The average seed cotton yield/plant ranged from 15.45 (Giza 70) to $33.84 \mathrm{~g}$ (Giza 83) with an overall average of $25.28 \mathrm{~g}$. Hybrid (Giza-81 x Giza-83) gave $(54.04 \mathrm{~g})$ the highest seed cotton yield at Assiut in the early sowing date. These results are in agreement with those obtained by El-Ameen (1994), Hassan (1996), Allam, (1997), Nazmey (2000) and Mohamed et al. (2005). 
Mohamed, A. A. et al.

Table 1. The combined analysis of variance for the studied traits of nine cotton genotypes over years, locations and sowing dates.

\begin{tabular}{|c|c|c|c|c|c|c|}
\hline \multirow[b]{2}{*}{$\begin{array}{l}\text { Source of } \\
\text { variation }\end{array}$} & \multirow[b]{2}{*}{ df } & \multicolumn{5}{|c|}{ Means of squares } \\
\hline & & $\begin{array}{c}\text { Seed cotton } \\
\text { yield/plant } \\
\text { (g) }\end{array}$ & $\begin{array}{l}\text { Lint yield/ } \\
\text { plant (g) }\end{array}$ & $\begin{array}{c}\text { Boll } \\
\text { weight } \\
\text { (g) }\end{array}$ & $\begin{array}{c}\text { Seed } \\
\text { index } \\
(\mathrm{g})\end{array}$ & $\begin{array}{c}\text { Lint } \\
\text { index } \\
\text { (g) }\end{array}$ \\
\hline Years $(Y)$ & 1 & $1703.93^{* *}$ & $289.28^{\star *}$ & $2.35^{* *}$ & $95.02^{* t}$ & $20.22^{* *}$ \\
\hline Location (L) & 1 & $3391.90^{* *}$ & $503.34^{\star *}$ & $4.28^{* *}$ & $35.25^{\star *}$ & $7.29^{* *}$ \\
\hline$Y \times L$ & 1 & $6801.45^{\star \star}$ & $1118.25^{\star \star}$ & $1.72^{\star *}$ & $35.98^{* *}$ & 0.90 \\
\hline Error (a) & 8 & 24.76 & 1.06 & 0.09 & 1.22 & 0.19 \\
\hline Dates (D) & 1 & $7873.14^{* *}$ & $1170.92^{* *}$ & $61.66^{* *}$ & $154.20^{* *}$ & $72.58^{* *}$ \\
\hline$Y \times D$ & 1 & $1023.34^{* *}$ & $156.15^{\star *}$ & $18.71^{* *}$ & $119.41^{* *}$ & $43.73^{* *}$ \\
\hline$L \times D$ & 1 & $1202.80^{* *}$ & $196.79^{* *}$ & 0.03 & 1.36 & 0.12 \\
\hline$Y \times L \times D$ & 1 & $2681.61^{* *}$ & $377.18^{\star *}$ & 0.01 & $31.48^{* *}$ & $14.00^{* *}$ \\
\hline Error (b) & 8 & 17.05 & 2.36 & 0.05 & 0.52 & 0.60 \\
\hline Genotypes (G) & 8 & $799.57^{* *}$ & $173.56^{* \star}$ & $0.67^{* *}$ & $2.38^{* *}$ & $3.96^{* *}$ \\
\hline$Y \times G$ & 8 & $284.31^{* *}$ & $44.90^{* *}$ & $0.34^{* *}$ & $3.49^{* *}$ & $2.81^{* *}$ \\
\hline$L \times G$ & 8 & $151.73^{* *}$ & $24.79^{* *}$ & $0.32^{* *}$ & 0.72 & 0.27 \\
\hline$Y \times L \times G$ & 8 & $38^{* *}$ & $68.69^{* *}$ & $0.23^{* *}$ & $22.65^{* *}$ & $2.53^{* *}$ \\
\hline $\mathrm{D} \times \mathrm{G}$ & 8 & 274 & $45.20^{* *}$ & $0.54^{* *}$ & $3.96^{* *}$ & $1.67^{\star *}$ \\
\hline$Y \times D \times G$ & 8 & $493.14^{* *}$ & $65.67^{\star *}$ & $0.37^{\star \star}$ & $7.26^{* *}$ & $9.01^{* *}$ \\
\hline$L \times D \times G$ & 8 & $191.11^{* *}$ & $26.19^{\star \star}$ & $0.18^{\star *}$ & 0.98 & 0.38 \\
\hline$Y \times L \times D \times G$ & 8 & $155.71^{\star *}$ & $25.02^{\star *}$ & 0.10 & $4.38^{* *}$ & $1.05^{\star}$ \\
\hline Error (c) & 128 & 23.66 & 3.59 & 0.06 & 0.64 & 0.41 \\
\hline
\end{tabular}

*,** Significant at 0.05 and 0.01 levels, respectively.

Table 2. Means of the studied traits over genotypes for years, locations and sowing dates.

\begin{tabular}{|l|c|c|c|c|c|}
\hline \multicolumn{1}{|c|}{ Item } & $\begin{array}{c}\text { Seed cotton } \\
\text { Yield/plant } \mathbf{( g )}\end{array}$ & $\begin{array}{c}\text { Lint yield/ } \\
\text { plant } \mathbf{( g )}\end{array}$ & $\begin{array}{c}\text { Boll weight } \\
\mathbf{( g )}\end{array}$ & $\begin{array}{c}\text { Seed index } \\
\mathbf{( g )}\end{array}$ & $\begin{array}{c}\text { Lint } \\
\text { index }\end{array}$ \\
\hline Year: & & & & & \\
\hline 1 & 28.09 & 10.57 & 2.12 & 7.04 & 4.13 \\
\hline 2 & 22.48 & 8.26 & 1.92 & 8.35 & 4.74 \\
\hline Location: & & & & & \\
\hline 1 & 29.25 & 10.94 & 2.16 & 8.10 & 4.62 \\
\hline 2 & 21.32 & 7.89 & 1.88 & 7.29 & 4.25 \\
\hline Sowing date: & & & & & \\
\hline 1 & 31.32 & 11.74 & 2.55 & 8.54 & 5.01 \\
\hline 2 & 19.25 & 7.09 & 1.49 & 6.85 & 3.86 \\
\hline
\end{tabular}

\section{2- Lint yield/plant (g):}

Results in Table 2 show that early sowing date gave higher lint yield/plant than late one. The early sowing date gave 14.22 and 9.26 compared to 7.66 and $6.51 \mathrm{~g}$ for late sowing in $L_{1}$ and $L_{2}$, respectively (Table $3)$. 
J. Agric. Sci. Mansoura Univ., 32 (1), January, 2007 
The average lint yield/plant ranged from 5.38 (Giza 70) to $13.43 \mathrm{~g}$ (Giza 83) with an overall average of $9.41 \mathrm{~g}$ (Table 3). The best genotype (Giza-81 $x$ Giza-83) gave lint yield of $21.75 \mathrm{~g}$ at Assiut in the early sowing date. These results are in harmony with those of El-Ameen (1994), Hassan (1996), Allam, (1997), Nazmey (2000) and Mohamed et al., (2005).

Delaying the sowing date by a month resulted in drastic reductions in seed cotton yield and its attributes which reached $62.70 \%$ for seed cotton yield and $65.58 \%$ for lint yield relative to the early sowing.

\section{3- Boll weight (g):}

The early sowing date gave 2.71 and 2.40 compared to 1.64 and $1.33 \mathrm{~g}$ for late sowing in $\mathrm{L}_{1}$ and $\mathrm{L}_{2}$, respectively (Table 3). Genotypes detected differential responses for either sowing dates or locations for boll weight (Table 3). The average boll weight ranged from 1.82 (Giza 85) to 2.35 $\mathrm{g}$ (Giza 80) with an overall average of $2.02 \mathrm{~g}$ (Table 3). The best genotype (Giza 70) showed boll weight of $2.93 \mathrm{~g}$ at Assiut in the early sowing date. Similar results were obtained by Hassan (1996), Allam, (1997), Nazmey (2000) and Mohamed et al. (2005).

\section{4- Seed index (g):}

Data in Table 2 exhibited that the early sowing date produced significantly heavier seeds than late sowing. The average seed index (Table 3) ranged from 7.08 (Giza70) to $8.21 \mathrm{~g}$ (dendara) with an overall average of $7.69 \mathrm{~g}$. The heaviest seeds was obtained from Giza 83 (9.88 g) at Assiut in the early sowing date. Similar results were obtained by Mohamed et al., (2005).

\section{5- Lint index (g):}

The early sowing dates gave lint index of 5.53 and 4.80 compared with 4.01 and $3.69 \mathrm{~g}$ for late one (Table 3 ). The average lint index ranged from 3.72 for Giza-70 to 4.89 for Giza-83 with an overall average of 4.43 $\mathrm{g}$. The highest lint index was obtained from Giza-83 (6.33 g) at Assiut in the early sowing date. Similar results were obtained by Hassan (1996), Allam, (1997), Nazmey (2000) and Mohamed et al. (2005).

\section{Stress susceptibility index:}

Stress susceptibility index (S) was used to estimate relative stress injury because it accounted for variation in yield potential and stress intensity. Low stress susceptibility $(S<1)$ is synonymous with higher stress tolerance (Fischer and Maurer, 1978). The differences in cotton yields between planting dates were larger than that between locations, therefore stress susceptibility index was calculated for each genotypes for sowing dates at each location. stress susceptibility index of seed cotton and lint yields (Table 3) showed that the most tolerant cultivar at Assiut was Giza 45 followed by Dendara, Giza 89 and Giza 70. However, at Qena the most tolerant cultivar was Giza 85 followed by Giza 80, Dendara and Giza 45. The other genotypes were susceptible to sowing dates.

It is of interest to indicate that the extra long staple cottons, Giza 45 and Giza 70 which showed stability towards sowing dates at Assiut, gave the lowest yields. It could be due to that these cultivars were selected, developed and adapted in Northern Nile Delta. On the other hand the susceptible cultivars to sowing dates gave the highest yield at late planting. The highest 
yielding cultivars in late planting at both locations was Giza 83 (susceptible) followed by Giza 80 and Giza 85 which were tolerant to sowing dates at Qena only. It could be concluded that the policy of planting each cultivar for a particular zone is correct irrespective of their susceptibility to sowing dates, because Giza 83, Giza 80 and Giza 85 are still the best high yielding cultivars at late planting at both of Assiut and Qena governorates.

In general, it could be noticed that delaying sowing date reduced seed cotton yield/plant, lint yield/plant, boll weight, seed index and lint index. Moreover, these results observed significant effects of years, locations, sowing dates and their different order interactions on the different genotypes for most of the studied traits. This means that the studied genotypes responded differently for sowing dates, years and locations which caused difficulty in demonstrating the significant superiority of any genotype for all locations and dates. Therefore, it may be informative to study the stability parameters of each genotype.

\section{b- Genotype-environment interaction and stability analysis:}

The joint regression analysis of variance for seed cotton yield/plant, lint yield/plant, boll weight and lint index are listed in Table 4 . The differences among genotypes were highly significant for these traits. Also, partitions of the genotypes $x$ environments interaction to Env. + (Gx Env.), Env.( Linear) and $G \times$ Env. (Linear) were significant and highly significant for all traits. The genotype $x$ environment (Linear) was significant, therefore, the stability analysis was performed according to Eberhart and Russell, (1966). This reflects that the change in the performance of a genotype from one location to another or genotypes showed different responses to yield and yield components when growing in different environments.

\section{1- Seed cotton yield/plant:}

The stability parameters (Table 5 and Fig. 1) show that the genotypes varied in their $b_{i}$ values as well as $S^{2} d_{i}$. It could be noticed that the intermediate yielding genotypes (Dendara, Giza 90, Giza 85 and Giza 89) were stable and ranged in yield from 22.95 to $26.69 \mathrm{~g}$. According to Eberhart and Russell (1966), the genotype Giza 89 considered to be superior because the regression coefficient of this genotype equal one $\left(b_{i}=1\right)$ and had a high yield when compared with the mean overall genotypes. However, the highest yielding genotypes [Giza 80, Giza 83 and (Giza 81x Giza 83)] which were unstable performed well at Qena (sub-optimal) in the early sowing date (24.64, 35.02 and $26.09 \mathrm{~g}$, respectively). Under conditions such as exist at Qena (sub-optimal) the breeder was obliged to recommended the highest yielding genotypes [Giza 80, Giza 83 and (Giza 81x Giza 83)] for such specific environments irrespective of their stability parameters. Tomar and Singh (1992) and El-Ameen (1994) found that low yielding genotypes were more stable than the rather responsive, high yielding ones. Similar results were obtained by Patil et al, (1991),Tomar and Rana (1992), El-Feki et al. (1994), El-Helow et al. (2002) and Mohamed et al. (2005).

\section{2- Lint yield/plant}

As shown in Table (5) and Fig. (1), the regression coefficient $\left(b_{i}\right)$ for two genotypes (Giza 85 and Giza 89 ) were insignificant from unity and the deviation from regression $\left(S^{2} d_{i}\right)$ were insignificant from zero, indicating that 
these genotypes considered to be stable for Lint yield/plant. Moreover, the same previous genotypes were also stable for seed cotton yield/plant . The other genotypes were unstable ( bi significantly different from one), three of them [Giza 80, Giza 83 and (Giza 81x Giza 83)] performed better in favourable environment because the regression coefficients $\left(b_{i}\right)$ were more than one. These results are in line with those reported by El-Ameen (1994), Patil et al., (1991),Tomar and Rana (1992), El-Feki et al., (1994), El-Helow et al., (2002) and Mohamed et al., (2005).

Table 4. The joint regression analysis of variance for seed cotton yield/plant, lint yield/plant, boll weight and lint index .

\begin{tabular}{|l|c|c|c|c|c|}
\hline \multirow{2}{*}{ S.O.V } & \multirow{2}{*}{$\mathbf{d f}$} & \multicolumn{4}{|c|}{ Mean squares } \\
\cline { 3 - 7 } & & $\begin{array}{c}\text { Seed cotton } \\
\text { yield/plant } \mathbf{( g )}\end{array}$ & $\begin{array}{c}\text { Lint } \\
\text { yield/plant } \\
\mathbf{( g )}\end{array}$ & $\begin{array}{c}\text { Boll } \\
\text { weight } \\
(\mathbf{g})\end{array}$ & $\begin{array}{c}\text { Lint index } \\
\mathbf{( g )}\end{array}$ \\
\hline Genotypes (G) & 8 & $266.51^{* *}$ & $57.87^{* *}$ & $0.20^{*}$ & $1.32^{*}$ \\
\hline Env. + (G $\times$ Env.) & 63 & $210.39^{* *}$ & $32.89^{* *}$ & $0.58^{* *}$ & $1.59^{* *}$ \\
\hline Env. (linear) & 1 & $8225.97^{* *}$ & $1270.71^{* *}$ & $30.55^{* *}$ & $52.98^{* *}$ \\
\hline G x Env. (linear) & 8 & $407.12^{* *}$ & $72.07^{* *}$ & $0.19^{*}$ & $1.69^{*}$ \\
\hline Pooled deviation & 54 & $32.81^{*}$ & 4.16 & 0.08 & $0.63^{* *}$ \\
\hline Pooled error & 128 & 23.66 & 3.59 & 0.06 & 0.41 \\
\hline
\end{tabular}

*,** Significant and highly Significant at 0.05 and 0.01 probability levels, respectively .

\section{3- Boll weight:}

Considering boll weight, six genotypes i.e., Dendara, Giza 45, Giza 85, Giza 81x Giza 83, Giza 80 and Giza 89 were stable (Table 5 and Fig. 1). The stable genotypes ranged in boll weight from 1.82 to $2.35 \mathrm{~g}$. Three of them were also stable for seed cotton yield. The remainder three genotypes i.e., Giza 90, Giza 83 and Giza70 were unstable ( bi significantly different from one). The performance of Giza 83 was relatively better in stress environments $(\mathrm{bi}<1.0)$. Similar results were obtained by Mohamed et al. (2005).

4- Lint index:

The data of lint index (Table 5 and Fig. 1) exhibited that all the studied genotypes except Giza 85 and Giza 80 were stable because these genotypes have regression coefficient $\left(b_{i}\right)$ which are not different from the unit slope and have $S^{2} d_{i}$ which are not significantly different from zero. The stable genotypes ranged in lint index from 3.72 to $4.89 \mathrm{~g}$. The performance of Giza 80 was relatively better in stress environments $(\mathrm{bi}<1.0)$. These results are in accordance with those reported by El-Feki et al. (1994), El-Helow et al. (2002) and Mohamed et al. (2005) .

From previous results, it is clear that the intermediate yielding genotypes were more stable than the rather responsive high yielding ones. However, the genotype Giza 89 was stable for yield and its attributes. In addition, it was relatively stress tolerant in Assiut (optimal environment).

Generally, it could be concluded that the best high yielding cultivars in late planting at Assiut and Qena governorate were Giza 83 and Giza 80 (unstable). 
J. Agric. Sci. Mansoura Univ., 32 (1), January, 2007 T5 
Mohamed, A. A. et al. 


\section{REFERENCES}

Allam, M. A. M.1997. Studies on genetic stability in some Egyptian cotton crosses. Ph. D. Thesis, Fac. Agric. Al-Azhar Univ., Cairo Egypt.

Cockerham, C. C. 1963. Estimation of genetic variance. P. 53-94. In W. D. Hanson and H. F. Robinson (ed) sta. Tistical genetics and plant breeding. NAS-NRC Publ-982. NAS, Washington, Dc.

Eberhart, S. A. and W. A. Russell. 1966. Stability prameters for comparing varieties . Crop Sci.,

6: 36-40.

El-Ameen, T. M. 1994. Genetic analysis of stability and control of variation for economic traits in Egyptian cotton. M. Sc. Thesis, Fac. Agric. Assiut Univ., Egypt.

El-Ameen, T. M. 1999. Selection under stress conditions for yield and quality attributes in Egyptian cotton. Ph. D. Thesis, Fac. Agric. Assiut Univ., Egypt.

El-Feki, T. A., Hanna, F. Fahmy, H. A. Abd- Alnaby and Sayieda, S. H. ElHelow. 1994. Stability parameters of Egyptian extra-long genotypes for yield and yield components. Proc. $6^{\text {th }}$ Conf. Agron. Al-Azhar Univ. Cairo Egypt. 1: Sept. 1994.

El-Helow, S., A. A. M. Awad, A. M. Zeina and M. A. Abd El-Gelil. 2002. Genetic stability for Egyptian extra-long staple cotton genotypes. Lint cotton yield and some lint properties. Alex. Sci. Exch. 23: 25-37.

El-Shaarawy, S. A., L. Haikal, M. R. Rahoumah, A. Zena and A. El-Nazer. 1994. Genotypic stability of Egyptian cotton strains for lint yield and yield components. Proceeding Belt wide cotton Conferences, January, 5-8 San Digo, C. A., USA Memphis, USA, National cotton Council. 679682 [C.F. Plant Breeding Abst. 66(1): 922, 1996].

Falconer, D. S. 1952. The problem of environment and selection. Am. Nat. 86: 293-298.

Fischer, R. A and R. Maurer. 1978. Drought resistance in spring wheat cultivars : 1-Grain yield response . Aust. J. Agric. Res., 29: 897-912 .

Gomez, K. A. and A. A. Gomez. 1984. Statistical Procedures for Agricultural Research. John Wiley \& Sons. Inc. New York, USA .

Hassan, I. S. M. 1996. Varieties by environment interaction and its effect on zaning Egyptian cotton. Ph. D. Thesis, Fac. Agric. Moshtohor, Zagazig Univ., Egypt.

Miller, P. A., J. C. Williams and H. F. Robinson. 1959. Variety $x$ environment interactions in cotton variety test and their implications of testing methods. Agron. J. 51: 132.

Mohamed, S. A. S., A. A. Mohamed and M. N. A. Nazmy. 2005. Mean performance and stability of some cotton genotypes ( $G$. barbadense L.) under six different locations in Egypt. Minia J. of Agric. Res. \& Develop. 3: $535-550$

Nazmey, M. N. A. 2000. A comparative study among some methods for evaluating stability in Egyptian cotton. Ph. D. Thesis, Fac. Agric. Moshtohor, Zagazig Univ., Egypt. 
Patil, F. B., Y. M. Shinde and M. V. Thombre. 1991. Heterosis in multiple environments for yield components and its relation with genetic divergence in cotton. Indian J. Genet., 51 (1): 118-124.

Robertson, A. 1959. The sampling variance of the genetic correlation coefficient. Biometrics. 15: 469-485.

Romagosa, I. and P. N. Fox. 1993. Genotypic x environment interaction and adaptation. In plant Breeding. [Ed. Hayward, M. D.; N. O. Bosemark and I. Romagosa] pp. 373-390. Chapman and Hall Press, London.

Sayieda, S. H. El-Helow. 2001. Genetic stability for Egyptian extra-long stable cotton genotypes. 1- Seed cotton yield and its some components. Egypt J. Appl. Sci., 16: 51-54.

Thomson, N. J. and R. B. Cunningham. 1979. Genotype x environment interactions and evaluation of cotton cultivars. Aust. Agric. Res. 30: 105-115.

Tomar, S. K. and O. S. Rana. 1992. Genotype x environment interaction for seed cotton yield in Asiatic cotton (Gossypium arboretum L.). Indian J. Agric. Sci. (62) 11: 778-779.

Tomar, S. K. and S. P. Singh. 1992. Phenotypic stability of hybrids and their parents for seed cotton yield and its components in Desicotton ( $G$. arboreum L.). Indian J. Genet. 52: 238-244.

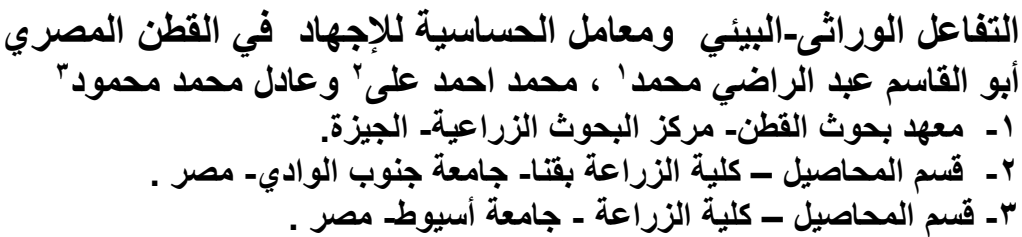

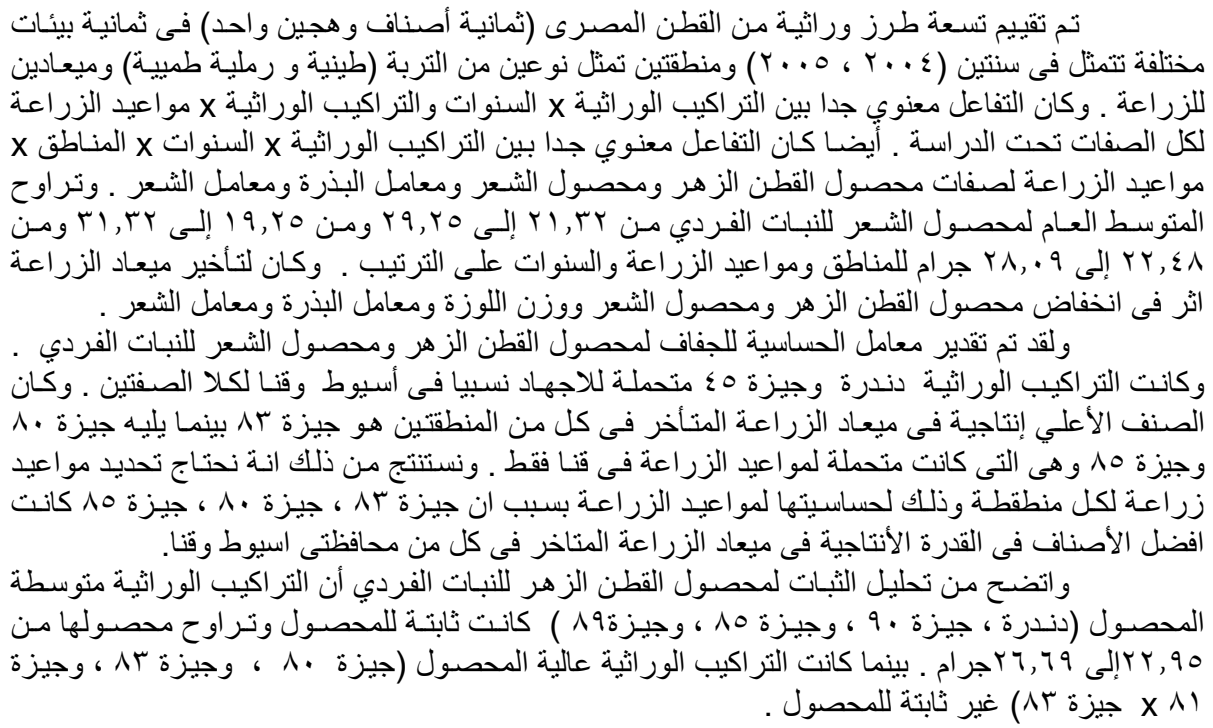


Table 3. Means of genotypes over years at the two locations and two sowing dates for the five traits and stress susceptibility index (S) for seed cotton yield/plant and lint yield/plant.

\begin{tabular}{|c|c|c|c|c|c|c|c|c|c|c|c|c|c|c|}
\hline \multirow[t]{3}{*}{ Genotypes } & \multicolumn{7}{|c|}{ Seed cotton yield/plant (g) } & \multicolumn{7}{|c|}{ Lint yield/plant (g) } \\
\hline & \multicolumn{3}{|c|}{$\mathrm{L}_{1}$} & \multicolumn{3}{|c|}{$\mathrm{L}_{2}$} & \multirow{2}{*}{$\begin{array}{l}\text { Mean } \\
\text { yield }\end{array}$} & \multicolumn{3}{|c|}{$L_{1}$} & \multicolumn{3}{|c|}{$\mathrm{L}_{2}$} & \multirow{2}{*}{\begin{tabular}{|l|} 
Mean \\
yield
\end{tabular}} \\
\hline & $D_{1}$ & $\mathrm{D}_{2}$ & $\mathbf{S}$ & $D_{1}$ & $D_{2}$ & $\mathbf{S}$ & & $D_{1}$ & $D_{2}$ & $\mathbf{S}$ & $D_{1}$ & $D_{2}$ & $\mathbf{S}$ & \\
\hline Dendara & 30.18 & 21.77 & 0.62 & 22.54 & 18.50 & 0.62 & 23.25 & 10.65 & 7.66 & 0.61 & 7.44 & 6.39 & 0.47 & 8.03 \\
\hline Giza 90 & 35.22 & 17.90 & 1.09 & 28.17 & 16.13 & 1.47 & 24.36 & 13.41 & 6.89 & 1.06 & 9.68 & 6.15 & 1.22 & 9.03 \\
\hline Giza 45 & 22.16 & 20.72 & 0.14 & 20.66 & 16.30 & 0.73 & 19.96 & 7.70 & 6.39 & 0.37 & 6.54 & 5.28 & 0.64 & 6.47 \\
\hline Giza 85 & 33.37 & 18.36 & 1.00 & 20.91 & 19.15 & 0.29 & 22.95 & 11.61 & 7.28 & 0.81 & 7.77 & 6.90 & 0.37 & 8.39 \\
\hline Giza 80 & 53.82 & 24.10 & 1.23 & 24.64 & 22.32 & 0.32 & 31.22 & 20.90 & 9.17 & 1.22 & 9.62 & 8.38 & 0.43 & 12.02 \\
\hline Giza 83 & 53.88 & 25.59 & 1.17 & 35.02 & 20.85 & 1.40 & 33.84 & 21.69 & 9.90 & 1.18 & 13.69 & 8.45 & 1.28 & 13.43 \\
\hline Giza70 & 21.80 & 12.96 & 0.90 & 15.91 & 11.15 & 1.03 & 15.45 & 7.15 & 4.38 & 0.84 & 6.31 & 3.69 & 1.38 & 5.38 \\
\hline Giza 89 & 35.77 & 23.39 & 0.77 & 31.06 & 16.56 & 1.61 & 26.69 & 13.17 & 8.92 & 0.70 & 11.48 & 6.35 & 1.49 & 9.98 \\
\hline Giza-81x Giza-83 & 54.04 & 21.41 & 1.34 & 26.09 & 17.83 & 1.09 & 29.84 & 21.75 & 8.33 & 1.34 & 10.81 & 7.04 & 1.16 & 11.98 \\
\hline Mean & 37.80 & 20.69 & & 25.00 & 17.64 & & 25.28 & 14.22 & 7.66 & & 9.26 & 6.51 & & 9.41 \\
\hline $\operatorname{LSD}_{0.05}$ & & & & & & & 2.75 & - & & & - & - & & 1.07 \\
\hline
\end{tabular}

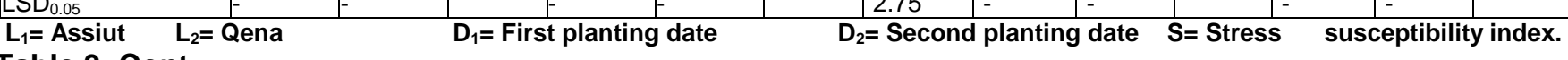

Table 3. Cont

\begin{tabular}{|c|c|c|c|c|c|c|c|c|c|c|c|c|c|c|c|}
\hline \multirow[t]{3}{*}{ Genotypes } & \multicolumn{5}{|c|}{ Boll weight } & \multicolumn{5}{|c|}{ Seed index (g) } & \multicolumn{5}{|c|}{ Lint index (g) } \\
\hline & \multicolumn{2}{|c|}{$\mathrm{L}_{1}$} & \multicolumn{2}{|c|}{$\mathrm{L}_{2}$} & \multirow[t]{2}{*}{ Mean } & \multicolumn{2}{|c|}{$\mathrm{L}_{1}$} & \multicolumn{2}{|c|}{$\mathrm{L}_{2}$} & \multirow[t]{2}{*}{ Mean } & \multicolumn{2}{|c|}{$\mathrm{L}_{1}$} & \multicolumn{2}{|c|}{$\mathrm{L}_{2}$} & \multirow[t]{2}{*}{ Mean } \\
\hline & $D_{1}$ & $D_{2}$ & $\mathrm{D}_{1}$ & $D_{2}$ & & $D_{1}$ & $D_{2}$ & $D_{1}$ & $D_{2}$ & & $D_{1}$ & $D_{2}$ & $D_{1}$ & $\mathrm{D}_{2}$ & \\
\hline Dendara & 2.48 & 1.56 & 2.27 & 1.28 & 1.90 & 8.66 & 8.24 & 8.27 & 7.69 & 8.21 & 4.80 & 4.52 & 4.47 & 3.97 & 4.44 \\
\hline Giza 90 & 2.77 & 1.93 & 2.32 & 1.33 & 2.09 & 9.45 & 7.30 & 8.31 & 6.59 & 7.91 & 5.75 & 4.54 & 5.23 & 3.85 & 4.84 \\
\hline Giza 45 & 2.54 & 1.43 & 2.31 & 1.22 & 1.88 & 8.79 & 7.68 & 8.26 & 6.6 & 7.84 & 4.53 & 3.90 & 4. & 3.31 & 3.96 \\
\hline Giza 85 & 2.55 & 1.31 & 2.33 & 1.09 & 1.82 & 9.70 & 6.35 & 8.06 & 6.14 & 7.56 & 5.58 & 3.32 & 5.08 & 3.23 & 4.30 \\
\hline Giza 80 & 2.92 & 2.02 & 2.69 & 1.76 & 2.35 & 8.13 & 7.63 & 8.07 & 7.21 & 7.76 & 5.00 & 4.22 & 4.93 & 3.79 & 4.49 \\
\hline Giza 83 & 2.74 & 2.16 & 2.16 & 1.58 & 2.16 & 9.88 & 6.76 & 8.53 & 5.96 & 7.78 & 6.33 & 4.16 & 4.98 & 4.09 & 4.89 \\
\hline Giza70 & 2.93 & 1.10 & 2.59 & 1.09 & 1.93 & 9.15 & 6.22 & 7.26 & 5.70 & 7.08 & 4.62 & 2.91 & 4.51 & 2.81 & 3.72 \\
\hline Giza 89 & 2.81 & 1.60 & 2.59 & 1.33 & 2.08 & 8.69 & 6.91 & 7.79 & 6.90 & 7.57 & 4.85 & 4.05 & 4.82 & 3.87 & 4.39 \\
\hline Giza81x 83 & 2.63 & 1.92 & 2.37 & 1.04 & 1.99 & 8.73 & 7.44 & 7.93 & 5.91 & 7.50 & 5.22 & 4.51 & 5.11 & 4.32 & 4.87 \\
\hline Mean & 2.71 & 1.64 & 2.40 & 1.33 & 2.02 & 9.02 & 7.17 & 8.05 & 6.52 & 7.69 & 5.53 & 4.01 & 4.80 & 3.69 & 4.43 \\
\hline $\mathrm{LSD}_{0.05}$ & - & - & - & - & 0.14 & - & - & - & - & 0.45 & - & - & - & - & 0.36 \\
\hline
\end{tabular}

$\mathrm{L}_{1}=$ Assiut $\quad \mathrm{L}_{2}=$ Qena $\quad \mathrm{D}_{1}=$ First planting date $\quad \mathrm{D}_{2}=$ Second planting date 
Table 5. Average performance of genotypes over eight environments and stability parameters of for seed cotton yield/plant, lint yield/plant, boll weight and lint index .

\begin{tabular}{|c|c|c|c|c|c|c|c|c|c|c|c|c|}
\hline \multirow[t]{2}{*}{ Genotypes } & \multicolumn{3}{|c|}{$\begin{array}{l}\text { Seed cotton } \\
\text { yield/plant (g) }\end{array}$} & \multicolumn{3}{|c|}{ Lint yield/plant (g) } & \multicolumn{3}{|c|}{ Boll weight (g) } & \multicolumn{3}{|c|}{ Lint index (g) } \\
\hline & - & $b_{i}$ & $S^{2} d_{i}$ & - & $\boldsymbol{b}_{i}$ & $S^{2} d_{i}$ & $\begin{array}{l}- \\
x\end{array}$ & $b_{i}$ & $S^{2} d_{i}$ & - & $b_{i}$ & $S^{2} d_{i}$ \\
\hline Dendara & 23.25 & 0.70 & 1.79 & 8.03 & $0.65^{\star}$ & -0.45 & 1.90 & 0.90 & -0.04 & 4.44 & 0.49 & -0.08 \\
\hline Giza 90 & 24.36 & 0.74 & -6.21 & 9.03 & $0.66^{*}$ & -0.92 & 2.09 & $0.69^{*}$ & 0.06 & 4.84 & 1.27 & 0.43 \\
\hline Giza 45 & 19.96 & $0.15^{\star \star}$ & 34.88 & 6.47 & $0.25^{* \star}$ & 3.28 & 1.88 & 1.20 & -0.01 & 3.96 & 0.85 & 0.12 \\
\hline Giza 85 & 22.95 & 0.96 & -9.68 & 8.39 & 0.76 & -1.60 & 1.82 & 1.10 & 0.01 & 4.30 & $1.67^{*}$ & -0.26 \\
\hline Giza 80 & 31.22 & $1.92^{* *}$ & 15.89 & 12.02 & $2.05^{\star *}$ & 3.39 & 2.35 & 0.94 & -0.01 & 4.49 & $0.10^{* *}$ & $1.34^{* *}$ \\
\hline Giza 83 & 33.84 & $1.60^{* *}$ & -18.16 & 13.43 & $1.66^{* *}$ & -3.05 & 2.16 & $0.63^{*}$ & 0.01 & 4.89 & 1.43 & -0.12 \\
\hline Giza70 & 15.45 & $0.10^{* *}$ & 28.18 & 5.38 & $0.11^{\star *}$ & 3.16 & 1.93 & $1.31^{*}$ & 0.02 & 3.72 & 0.95 & 0.01 \\
\hline Giza 89 & 26.69 & 1.01 & 19.31 & 9.98 & 0.91 & 2.66 & 2.08 & 1.22 & 0.09 & 4.39 & 1.33 & 0.10 \\
\hline Giza 81x Giza 83 & 29.84 & $1.82^{* *}$ & 16.36 & 11.98 & $1.94^{* *}$ & -1.32 & 1.99 & 1.02 & 0.05 & 4.87 & 1.10 & 0.40 \\
\hline Mean & 25.28 & - & - & 9.41 & - & - & 2.02 & - & - & 4.43 & - & - \\
\hline LSD $_{0.05}$ & 2.75 & - & - & 1.07 & - & - & 0.14 & - & - & 0.36 & - & - \\
\hline
\end{tabular}

*,** Significantly different from unity for (bi) and from zero for $\left(\mathrm{S}^{2} \mathrm{~d}_{\mathrm{i}}\right)$ at 0.05 and 0.01 probability levels, respectively . 